\title{
Polish 2012 growth references for preschool children
}

\author{
Zbigniew Kulaga • Aneta Grajda • Beata Gurzkowska • \\ Magdalena Góźdź • Malgorzata Wojtyło • Anna Świąder • \\ Agnieszka Różdżyńska-Świątkowska • Mieczysław Litwin
}

Received: 7 November 2012 / Accepted: 22 January 2013 / Published online: 1 February 2013

(C) The Author(s) 2013. This article is published with open access at Springerlink.com

\begin{abstract}
Growth references are useful in monitoring a child's growth, which is an essential part of child care. The aim of this paper is to provide updated growth references for Polish preschool children and to assess how well children in Poland match or diverge from the World Health Organization (WHO) growth standards/references and recent German height-for-age references. The height-, weight-, body mass index-for-age, and weight-for-height references were constructed with the LMS method using data from a recent, large, population-representative sample of 4,941 preschool children aged 3 to 6 years (the OLA study). In the case of boys, the third, 50th, and 97th height percentiles of new Polish and German references overlap almost completely, whereas the WHO growth standards/references percentiles are systematically lower. In the case of girls, comparison between the new Polish and German height references showed conformity on the third and 50th percentile, whereas body height values of the WHO standards/references are shorter. Polish children aged 3 to 6 years from for the nation representative sample, had significantly greater than zero mean $z$ scores of height-, weight-, and BMI-for-age and
\end{abstract}

Z. Kułaga $(\bowtie) \cdot$ A. Grajda • B. Gurzkowska $\cdot$ M. Góźdź $\cdot$

M. Wojtyło

Public Health Department, Children's Memorial Health Institute,

Al. Dzieci Polskich 20, 04-730 Warsaw, Poland

e-mail: z.kulaga@czd.pl

URL: www.czd.pl

A. Świąder · A. Różdżyńska-Świątkowska

Department of Paediatrics, Children's Memorial Health Institute, Al. Dzieci Polskich 20, 04-730 Warsaw, Poland

M. Litwin

Nephrology and Hypertension Department, Children's Memorial Health Institute, Al. Dzieci Polskich 20, 04-730 Warsaw, Poland weight-for-height, relative to the WHO growth standards/references. The number of children in the sample with heightfor-age below $-2 \mathrm{SD}$ was significantly lower than expected and number of children with height-for-age above $+2 \mathrm{SD}$ was significantly higher than expected. Conclusion: The OLA study growth references can be recommended as national references for preschool children in Poland.

Keywords Preschool children · Growth references · LMS method

\section{Introduction}

Children's growth monitoring to identify medical disorders or nutrition-related problems is an important task of medical professionals providing health care for children. Optimal growth monitoring requires up-to-date reference growth data on representative samples from the population and growth references constructed according to the state-of-the-art statistical methodologies [5]. Reference charts for preschool children that were until recently used in Poland were based on the sample representative for capital city (Warsaw) and were constructed without accounting for skewness of weight and body mass index (BMI) [18]. In 2006, the World Health Organization (WHO) published results of the Multicentre Growth Reference Study (MGRS) and new international growth standards based on measurements taken from healthy breastfed infants and children under 5 years, living in six countries on different continents "under conditions likely to favor the achievement of their full genetic growth potential" [24]. Therefore the MGRS sample could be regarded as universal reference population and there is a noticeable interest for the idea of implementing these charts 
[9]. However, children's development depends on various genetic and socio-economic factors which are different in different parts of the world and typical for ethnic groups. Thus, growth references should be not only specific for ethnic group but also should be periodically actualized to adjust to changes in socio-economical situation. In previous studies on distribution of height, weight, and BMI in Polish school-aged children, significant differences from international growth references including the WHO growth references for children and adolescents aged 5-19 years were found $[15,16]$. Similar observations on taller children in nationally representative sample than children representing the WHO growth standards/references came recently from Germany [21].

In this paper, we present cross-sectional height-, weight-, BMI-for-age, and weight-for-height references for preschool children in Poland using data from a current, representative sample of Polish children aged 3-6 years. We also took advantage of a recent, large sample of preschool children to assess how well children in Poland match or diverge from the WHO Child Growth Standards and recent German height-for-age references.

\section{Materials and methods}

\section{Design, setting, and subjects}

We analyzed anthropometric data collected in the course of population-based cross-sectional OLA study (N R13 0002 06), which main purpose was to assess distribution of blood pressure and construct blood pressure percentiles for Polish preschool children. Field examinations were conducted in 81 primary health care practices in all regions of Poland between November 2010 and May 2012. Approval of the Children's Memorial Health Institute Ethics Committee to conduct the study was obtained before the study commenced. Informed consent was obtained in written form from parent of each participating child. Study participants (children 2.5-6.5 years of age) were randomly selected using two-stage sampling. The sampling frame at the first stage consisted of a list of primary health care practices obtained from regional offices of National Health Fund. Sampling was stratified by province. In the second stage, all children in the required age range within the sampled primary health care setting comprised the sampling frame. The information on date of birth, pregnancy duration, and birth weight (BW) was obtained from the Child Health Handbooks. Parents were interviewed on duration of breastfeeding, introduction of complementary feeding, child's pharmacotherapy in the month preceding the survey, and on medical history of the child. The general health status including medical history and physical examination of each subject was assessed by a physician. Children with disorders possibly affecting growth were excluded from the study; exclusion criteria were: postural deficiencies, genetic syndromes (Down syndrome, Turner syndrome), cancer, or other chronic disease influencing height, including children treated with growth hormone or diagnosed with growth hormone deficiency, children treated with systemic steroids for any reason, diabetes, cerebral palsy, thyroid hormone supplementation, cystic fibrosis, renal disease, congenital adrenal hyperplasia, and congenital heart defect with impairment of physical fitness.

\section{Anthropometric techniques}

Height and weight were recorded in duplicate. Height was measured using a SECA 214 stadiometer. The subject was in the standing upright position (no shoes), with hips and shoulders perpendicular to the central axis, heels against the footboard, knees together, arms hanging loosely at the sides, and the head in the Frankfurt plane. Height was recorded to the nearest millimeter, if a difference between measurements exceeded $4 \mathrm{~mm}$, a third measurement was performed. Body weight was recorded in light underwear to the nearest $0.05 \mathrm{~kg}$, using a digital medical scale (Radwag WPT $100 / 200$, Poland). In the case of a difference between measurements equal to or exceeding $0.3 \mathrm{~kg}$, a third measurement was taken. Body mass index was calculated as body weight divided by height in meters squared.

All measurements were taken by trained staff: anthropologists, nurses, public health professionals, and physicians using standard and calibrated equipment. The training consisted of presentation of the standardized measuring techniques and practical exercises supervised by the trainer. Following the training, standardization sessions were conducted according to the standardization protocol. Reliability of anthropometric measurements between the trainer and the trainee (study staff) was documented.

\section{Statistical analysis}

Statistical analyses were performed separately for boys and girls using SAS 9.2 software. Exact age was calculated by subtracting the date of birth from the date of examination. Outliers were identified by inspecting the $z$ score plot of the variable under consideration, and were checked carefully for possible mistakes of data recording and/or transfer. None of the outliers was considered to be biologically implausible and there were no outlier exclusions from the dataset.

Height-for-age, weight-for-age, BMI-for-age, and weightfor-height percentile curves were constructed separately for each sex using the LMS method [3] and LMSChartMaker Pro version 2.42 software [19]. In order to provide a smooth transition from the Polish 2012 preschool growth references 
curves beyond age of 6 years, data of the OLA study were merged with data of the OLAF study, which provided Polish 2010 growth references for school-aged children and adolescents [15]. A Box-Cox power transformation was used to normalize the data at each age. Natural cubic splines with knots at each distinct age $t$ were fitted by maximum penalized likelihood to create three smooth curves: $L(t)$ the Box-Cox power, $M(t)$ the median, and $S(t)$ the coefficient of variation percentile curves at age were then obtained as

$C_{100 \alpha}(t)=M(t)\left[1+L(t) S(t) Z_{\alpha}\right]^{1 / L(t)}$

where $Z_{\alpha}$ is the normal equivalent deviate for tail area $a_{\alpha}$, and $\mathrm{C} 100_{\alpha}(t)$ is the percentile corresponding to $Z_{\alpha}$. Equivalent degrees of freedom (edf) $L(t), M(t)$, and $S(t)$ measure the complexity of each fitted curve. With the use of the LMS method each observation can be converted to its standard deviation score $(Z)$ with the formula: $Z=\frac{\left[\frac{[\text { measurement }}{M}\right]^{L}-1}{L S}$ if $L \neq 0$ or $Z=\log \frac{\frac{[\text { measurement }]}{M}}{S}$ if $L=0$.

$Q$ tests [20, 22] and inspection of worm-plots [23] were used to check the goodness of fit of selected models.

Comparison with the WHO growth standards/references and current German height-for-age reference

The third, 50th, and 97th height percentiles for ages 3-6 years of the WHO growth standards/references, German height references [21] and new Polish 2012 height references were compared graphically. The BMI $z$ scores curves: $-2 ;-1 ; 0 ; 1$; and 2 of new Polish 2012 references were compared to the WHO growth standards/references.

Age- and sex-adjusted $z$-scores for height (HAZ), weight (WAZ), BMI (BMIZ), and weight-for-height $z$ scores (WHZ) were calculated for each child in the sample relative to the WHO growth standards/references. In the case of children aged 3-5 years (exact ages, 914-1,856 days) SAS macro, software provided by the WHO, was used to calculate the indicators of the attained growth standards [10]; in the case of children aged 5-6 years (exact ages, 1,857-2,373 days) WHO SAS macro available to analyze growth data for the age group 5-19 years was used $[8,11]$. Birth weight $z$ scores (BWZ) were calculated for each child in the sample relative to the WHO growth standards according to the formula: $\mathrm{BWZ}=$ $\left((\mathrm{BW} / M)^{\wedge} L-1\right) / L / S$.

where $L, M, S$ were derived from the WHO growth standards at age "0" [24]. Summary data were presented as means and $95 \%$ confidence interval $(\mathrm{CI})$ for the mean for the total sample and for the subsample of children exclusively breastfed for at least 4 months. Differences in the prevalence of stunting (percentage less than -2 SD of HAZ) and in the prevalence of height $>+2$ SD between the WHO height-forage standards/references and new Polish 2012 height-for-age references were tested with chi-square test. Differences were considered significant when $p$ values were less than 0.05 .

\section{Results}

There were 7,545 children drawn and invited to take part in the study, of whom parents of 5,050 children (aged 2.5-6.5 years) consented and were enrolled into the study (response rate $67 \%$ ). Forty percent of study subjects were living in rural areas which reflected the national proportion. Data from 109 children were excluded from the analyses due to lack of height or weight measurement (child's refusal to cooperate during anthropometry measurement according to the protocol set requirements), or invalid data (e.g., lack of second measurement or third measurement in the case that third measurement was required), or health defined exclusion criteria. Thus, the sample comprised 2,437 healthy boys (49 \%) and 2,504 healthy girls. Mean BW was 3,465 and $3,313 \mathrm{~g}$, in the case of boys and girls, respectively, which reflect mean $z$ scores, calculated relative to the WHO growth standards, of 0.18 (95\% CI, 0.13-0.22) and 0.11 (95\% CI, 0.07-0.16), boys and girls, respectively. Table 1 provides sample size by age and sex and descriptive statistics.

\section{Polish 2012 height, weight, and BMI references}

Among both boys and girls height and weight increased with age, whereas BMI declined from age 3 years reaching its lowest median value of 15.5 and $15.4 \mathrm{~kg} / \mathrm{m}^{2}$ in boys and girls, respectively, at the age of 5. Median BMI increased from age 5 years to age 6 years in both boys and girls.

In the construction of height-for-age and weigh-for-age reference percentiles the same edf parameters were used as in the construction of Polish 2010 height- and weight-forage for school-aged children [15] and age was rescaled in the LMSChartMaker, as both height and weight changed with age monotonously.

The reference height percentiles for boys and girls were constructed without skewness. The Box-Cox power transformations $L$ for height were set to 1 at all ages. In the case of weight LMS models, positive skewness was observed in all ages; smoothed $L$ values for weight varied between -1.42 and -1.14 . As in the case of weight-for-age distribution, BMI distribution was skewed to the right in all ages. The smoothed $L$ values for the BMI varied from -2.74 to -1.86 . The BMI edf parameters were: L2M5S5 and L3M5S5, boys and girls, respectively. Since BMI did not change with age monotonously, original age was used in the LMSChartMaker for fitting 
Table 1 Characteristic of Polish 2012 preschool children growth references sample

\begin{tabular}{|c|c|c|c|c|c|c|c|c|c|c|c|}
\hline \multirow[t]{2}{*}{ Age (years) } & \multirow[t]{2}{*}{ Variable } & \multicolumn{5}{|c|}{ Boys } & \multicolumn{5}{|c|}{ Girls } \\
\hline & & $N$ & Mean & $\mathrm{SD}$ & Min & Max & $N$ & Mean & SD & Min & Max \\
\hline \multirow[t]{3}{*}{3} & Height (cm) & 595 & 98.3 & 4.2 & 85.7 & 114.0 & 582 & 96.9 & 4.3 & 83.4 & 113.2 \\
\hline & Weight (kg) & & 15.5 & 2.3 & 10.4 & 30.4 & & 14.9 & 2.1 & 10.6 & 26.5 \\
\hline & BMI $\left(\mathrm{kg} / \mathrm{m}^{2}\right)$ & & 16.0 & 1.6 & 12.4 & 24.7 & & 15.9 & 1.5 & 12.4 & 23.8 \\
\hline \multirow[t]{3}{*}{4} & Height (cm) & 666 & 104.9 & 4.7 & 91.4 & 122.9 & 691 & 103.6 & 4.6 & 87.7 & 119.2 \\
\hline & Weight (kg) & & 17.5 & 2.7 & 12.4 & 32.0 & & 17.0 & 2.9 & 11.3 & 32.5 \\
\hline & BMI $\left(\mathrm{kg} / \mathrm{m}^{2}\right)$ & & 15.8 & 1.7 & 12.2 & 26.7 & & 15.8 & 1.8 & 11.6 & 26.6 \\
\hline \multirow[t]{3}{*}{5} & Height $(\mathrm{cm})$ & 615 & 111.8 & 4.9 & 97.8 & 127.5 & 658 & 110.4 & 5.0 & 96.5 & 129.4 \\
\hline & Weight (kg) & & 19.7 & 3.3 & 13.2 & 35.5 & & 19.1 & 3.4 & 12.1 & 38.3 \\
\hline & BMI $\left(\mathrm{kg} / \mathrm{m}^{2}\right)$ & & 15.7 & 1.8 & 12.0 & 27.1 & & 15.6 & 1.8 & 11.3 & 23.9 \\
\hline \multirow[t]{3}{*}{6} & Height (cm) & 561 & 118.3 & 5.5 & 106.6 & 136.5 & 573 & 116.9 & 5.5 & 100.7 & 134.1 \\
\hline & Weight $(\mathrm{kg})$ & & 22.3 & 4.3 & 15.4 & 42.9 & & 21.7 & 4.2 & 12.8 & 44.0 \\
\hline & BMI $\left(\mathrm{kg} / \mathrm{m}^{2}\right)$ & & 15.9 & 2.1 & 11.8 & 25.0 & & 15.7 & 2.1 & 9.3 & 27.5 \\
\hline
\end{tabular}

BMI references. Tables 2 and 3 show height, weight, and BMI references by age in boys and girls, respectively. Table 4 shows weight-for-height references for boys and girls. The weight-for-height edf parameters were:
L3M7S6 and L5M8S6, boys and girls, respectively. Since weight changed with height monotonously, we used the rescaled function in the LMSChartMaker, which improves the fit.

Table 2 Polish 2012 height-for-age (in $\mathrm{cm}$ ), weight-for-age (in $\mathrm{kg}$ ), and BMI-for-age (in $\mathrm{kg} / \mathrm{m}^{2}$ ) references for preschool boys

\begin{tabular}{|c|c|c|c|c|c|c|c|c|c|c|c|c|c|}
\hline $\begin{array}{l}\text { Age } \\
\text { (years) }\end{array}$ & $\mathrm{L}$ & $\mathrm{S}$ & $-2 \mathrm{SD}$ & $-1 \mathrm{SD}$ & $+1 \mathrm{SD}$ & $+2 \mathrm{SD}$ & P3 & P10 & $\mathrm{P} 25$ & $\begin{array}{l}\text { P50: M } \\
\text { (median) }\end{array}$ & P75 & P90 & P97 \\
\hline \multicolumn{14}{|c|}{ Height (cm) } \\
\hline 3.0 & 1 & 0.038 & 90.1 & 93.8 & 101.3 & 105.0 & 90.5 & 92.7 & 95.0 & 97.5 & 100.0 & 102.3 & 104.5 \\
\hline 3.5 & 1 & 0.039 & 93.5 & 97.4 & 105.2 & 109.2 & 93.9 & 96.3 & 98.7 & 101.3 & 104.0 & 106.3 & 108.7 \\
\hline 4.0 & 1 & 0.039 & 96.7 & 100.8 & 109.1 & 113.2 & 97.2 & 99.7 & 102.2 & 104.9 & 107.7 & 110.2 & 112.7 \\
\hline 4.5 & 1 & 0.040 & 99.8 & 104.1 & 112.7 & 117.0 & 100.3 & 102.9 & 105.5 & 108.4 & 111.3 & 113.9 & 116.5 \\
\hline 5.0 & 1 & 0.041 & 102.7 & 107.3 & 116.4 & 120.9 & 103.3 & 106.0 & 108.8 & 111.8 & 114.9 & 117.6 & 120.4 \\
\hline 5.5 & 1 & 0.041 & 105.6 & 110.4 & 119.9 & 124.7 & 106.2 & 109.0 & 111.9 & 115.2 & 118.4 & 121.3 & 124.1 \\
\hline 6.0 & 1 & 0.042 & 108.4 & 113.4 & 123.4 & 128.4 & 109.0 & 112.0 & 115.0 & 118.4 & 121.8 & 124.8 & 127.8 \\
\hline \multicolumn{14}{|c|}{ Weight (kg) } \\
\hline 3.0 & -1.289 & 0.131 & 11.9 & 13.2 & 17.2 & 20.6 & 12.1 & 12.8 & 13.7 & 14.9 & 16.4 & 18.0 & 20.1 \\
\hline 3.5 & -1.350 & 0.131 & 12.8 & 14.2 & 18.5 & 22.1 & 12.9 & 13.8 & 14.7 & 16.0 & 17.6 & 19.4 & 21.6 \\
\hline 4.0 & -1.382 & 0.130 & 13.7 & 15.2 & 19.8 & 23.7 & 13.9 & 14.7 & 15.8 & 17.1 & 18.8 & 20.7 & 23.1 \\
\hline 4.5 & -1.379 & 0.134 & 14.4 & 16.0 & 21.0 & 25.3 & 14.6 & 15.5 & 16.6 & 18.1 & 20.0 & 22.1 & 24.7 \\
\hline 5.0 & -1.369 & 0.142 & 15.0 & 16.8 & 22.4 & 27.5 & 15.2 & 16.3 & 17.5 & 19.1 & 21.2 & 23.6 & 26.7 \\
\hline 5.5 & -1.384 & 0.152 & 15.7 & 17.7 & 24.0 & 30.1 & 15.9 & 17.1 & 18.4 & 20.3 & 22.6 & 25.4 & 29.2 \\
\hline 6.0 & -1.416 & 0.163 & 16.6 & 18.7 & 26.0 & 33.5 & 16.8 & 18.0 & 19.5 & 21.6 & 24.4 & 27.7 & 32.3 \\
\hline \multicolumn{14}{|c|}{ BMI $\left(\mathrm{kg} / \mathrm{m}^{2}\right)$} \\
\hline 3.0 & -2.743 & 0.081 & 13.7 & 14.6 & 17.1 & 19.4 & 13.8 & 14.3 & 14.9 & 15.7 & 16.6 & 17.7 & 19.0 \\
\hline 3.5 & -2.696 & 0.085 & 13.6 & 14.4 & 17.2 & 19.6 & 13.7 & 14.2 & 14.8 & 15.6 & 16.6 & 17.8 & 19.2 \\
\hline 4.0 & -2.648 & 0.090 & 13.4 & 14.4 & 17.2 & 19.8 & 13.5 & 14.1 & 14.7 & 15.6 & 16.6 & 17.8 & 19.4 \\
\hline 4.5 & -2.601 & 0.094 & 13.3 & 14.3 & 17.3 & 20.1 & 13.4 & 14.0 & 14.6 & 15.5 & 16.6 & 18.0 & 19.7 \\
\hline 5.0 & -2.554 & 0.099 & 13.2 & 14.2 & 17.4 & 20.5 & 13.3 & 13.9 & 14.6 & 15.5 & 16.7 & 18.1 & 20.0 \\
\hline 5.5 & -2.507 & 0.104 & 13.1 & 14.2 & 17.5 & 20.9 & 13.3 & 13.9 & 14.6 & 15.5 & 16.8 & 18.3 & 20.4 \\
\hline 6.0 & -2.460 & 0.109 & 13.1 & 14.2 & 17.7 & 21.4 & 13.2 & 13.8 & 14.6 & 15.6 & 16.9 & 18.5 & 20.8 \\
\hline
\end{tabular}


Table 3 Polish 2012 height-for-age (in $\mathrm{cm}$ ), weight-for-age (in $\mathrm{kg}$ ), and BMI-for-age (in $\mathrm{kg} / \mathrm{m}^{2}$ ) references for preschool girls

\begin{tabular}{|c|c|c|c|c|c|c|c|c|c|c|c|c|c|}
\hline $\begin{array}{l}\text { Age } \\
\text { (years) }\end{array}$ & $\mathrm{L}$ & $\mathrm{S}$ & $-2 \mathrm{SD}$ & $-1 \mathrm{SD}$ & $+1 \mathrm{SD}$ & $+2 \mathrm{SD}$ & P3 & P10 & P25 & $\begin{array}{l}\text { P50: M } \\
\text { (median) }\end{array}$ & P75 & P90 & P97 \\
\hline \multicolumn{14}{|c|}{ Height (cm) } \\
\hline 3.0 & 1 & 0.040 & 88.7 & 92.5 & 100.2 & 104.0 & 89.1 & 91.4 & 93.7 & 96.3 & 98.9 & 101.2 & 103.5 \\
\hline 3.5 & 1 & 0.040 & 92.1 & 96.1 & 104.0 & 108.0 & 92.6 & 95.0 & 97.4 & 100.1 & 102.7 & 105.1 & 107.5 \\
\hline 4.0 & 1 & 0.040 & 95.3 & 99.5 & 107.8 & 112.0 & 95.8 & 98.3 & 100.9 & 103.7 & 106.5 & 109.0 & 111.5 \\
\hline 4.5 & 1 & 0.041 & 98.4 & 102.8 & 111.6 & 115.9 & 98.9 & 101.6 & 104.2 & 107.2 & 110.1 & 112.8 & 115.4 \\
\hline 5.0 & 1 & 0.042 & 101.3 & 105.9 & 115.1 & 119.7 & 101.9 & 104.6 & 107.4 & 110.5 & 113.6 & 116.4 & 119.2 \\
\hline 5.5 & 1 & 0.042 & 104.2 & 109.0 & 118.6 & 123.4 & 104.7 & 107.6 & 110.5 & 113.8 & 117.0 & 120.0 & 122.9 \\
\hline 6.0 & 1 & 0.043 & 107.0 & 112.0 & 122.0 & 127.0 & 107.6 & 110.6 & 113.6 & 117.0 & 120.4 & 123.4 & 126.4 \\
\hline \multicolumn{14}{|c|}{ Weight (kg) } \\
\hline 3.0 & -1.211 & 0.129 & 11.6 & 12.9 & 16.7 & 19.8 & 11.7 & 12.5 & 13.4 & 14.5 & 15.9 & 17.5 & 19.4 \\
\hline 3.5 & -1.202 & 0.135 & 12.3 & 13.7 & 18.0 & 21.6 & 12.4 & 13.3 & 14.3 & 15.5 & 17.1 & 18.9 & 21.1 \\
\hline 4.0 & -1.192 & 0.141 & 13.0 & 14.5 & 19.3 & 23.4 & 13.2 & 14.1 & 15.1 & 16.6 & 18.3 & 20.3 & 22.8 \\
\hline 4.5 & -1.182 & 0.147 & 13.7 & 15.4 & 20.7 & 25.3 & 13.9 & 14.9 & 16.0 & 17.6 & 19.6 & 21.8 & 24.6 \\
\hline 5.0 & -1.170 & 0.153 & 14.4 & 16.2 & 22.1 & 27.3 & 14.6 & 15.6 & 16.9 & 18.7 & 20.8 & 23.3 & 26.5 \\
\hline 5.5 & -1.157 & 0.158 & 15.1 & 17.1 & 23.5 & 29.3 & 15.3 & 16.5 & 17.9 & 19.8 & 22.2 & 24.9 & 28.5 \\
\hline 6.0 & -1.142 & 0.164 & 15.9 & 18.0 & 25.1 & 31.6 & 16.1 & 17.4 & 18.9 & 21.0 & 23.6 & 26.6 & 30.6 \\
\hline \multicolumn{14}{|c|}{ BMI $\left(\mathrm{kg} / \mathrm{m}^{2}\right)$} \\
\hline 3.0 & -2.094 & 0.085 & 13.5 & 14.4 & 17.1 & 19.2 & 13.6 & 14.1 & 14.8 & 15.6 & 16.6 & 17.6 & 18.9 \\
\hline 3.5 & -2.054 & 0.090 & 13.3 & 14.3 & 17.2 & 19.5 & 13.4 & 14.0 & 14.7 & 15.5 & 16.6 & 17.7 & 19.1 \\
\hline 4.0 & -2.013 & 0.095 & 13.2 & 14.2 & 17.2 & 19.7 & 13.3 & 13.9 & 14.6 & 15.5 & 16.6 & 17.8 & 19.3 \\
\hline 4.5 & -1.973 & 0.100 & 13.1 & 14.1 & 17.3 & 20.0 & 13.2 & 13.8 & 14.5 & 15.5 & 16.6 & 17.9 & 19.6 \\
\hline 5.0 & -1.933 & 0.105 & 12.9 & 14.0 & 17.4 & 20.2 & 13.1 & 13.7 & 14.4 & 15.4 & 16.7 & 18.1 & 19.8 \\
\hline 5.5 & -1.894 & 0.110 & 12.9 & 14.0 & 17.5 & 20.6 & 13.0 & 13.6 & 14.4 & 15.5 & 16.7 & 18.2 & 20.1 \\
\hline 6.0 & -1.857 & 0.115 & 12.8 & 14.0 & 17.6 & 20.9 & 12.9 & 13.6 & 14.4 & 15.5 & 16.9 & 18.4 & 20.5 \\
\hline
\end{tabular}

Table 4 Polish 2012 weight-for-height (in $\mathrm{kg}$ ) references for preschool boys and girls

\begin{tabular}{|c|c|c|c|c|c|c|c|c|c|c|c|c|c|}
\hline Height (cm) & $\mathrm{L}$ & $\mathrm{S}$ & $-2 \mathrm{SD}$ & $-1 \mathrm{SD}$ & $+1 \mathrm{SD}$ & $+2 \mathrm{SD}$ & P3 & $\mathrm{P} 10$ & P25 & $\begin{array}{l}\text { P50: M } \\
\text { (median) }\end{array}$ & P75 & P90 & P97 \\
\hline \multicolumn{14}{|l|}{ Boys } \\
\hline 90 & -2.591 & 0.073 & 10.9 & 11.6 & 13.4 & 14.9 & 11.0 & 11.4 & 11.8 & 12.4 & 13.0 & 13.8 & 14.7 \\
\hline 95 & -2.549 & 0.078 & 12.3 & 13.1 & 15.3 & 17.1 & 12.4 & 12.8 & 13.3 & 14.0 & 14.8 & 15.7 & 16.8 \\
\hline 100 & -2.509 & 0.083 & 13.6 & 14.4 & 17.1 & 19.3 & 13.7 & 14.2 & 14.8 & 15.6 & 16.5 & 17.6 & 19.0 \\
\hline 105 & -2.469 & 0.088 & 14.8 & 15.8 & 18.8 & 21.5 & 14.9 & 15.5 & 16.1 & 17.1 & 18.2 & 19.5 & 21.1 \\
\hline 110 & -2.428 & 0.093 & 16.0 & 17.1 & 20.7 & 23.8 & 16.1 & 16.8 & 17.6 & 18.6 & 19.9 & 21.4 & 23.3 \\
\hline 115 & -2.381 & 0.098 & 17.3 & 18.6 & 22.8 & 26.5 & 17.5 & 18.2 & 19.1 & 20.3 & 21.9 & 23.6 & 25.9 \\
\hline 120 & -2.326 & 0.104 & 18.9 & 20.4 & 25.2 & 29.8 & 19.0 & 19.9 & 20.9 & 22.4 & 24.1 & 26.3 & 29.1 \\
\hline 125 & -2.262 & 0.112 & 20.5 & 22.3 & 28.0 & 33.6 & 20.7 & 21.7 & 23.0 & 24.6 & 26.7 & 29.3 & 32.7 \\
\hline \multicolumn{14}{|l|}{ Girls } \\
\hline 90 & -1.648 & 0.079 & 10.9 & 11.7 & 13.7 & 15.1 & 11.0 & 11.5 & 12.0 & 12.6 & 13.3 & 14.1 & 14.9 \\
\hline 95 & -1.674 & 0.084 & 12.0 & 12.9 & 15.3 & 17.0 & 12.1 & 12.6 & 13.2 & 13.9 & 14.8 & 15.7 & 16.7 \\
\hline 100 & -1.703 & 0.089 & 13.2 & 14.2 & 17.0 & 19.0 & 13.3 & 13.9 & 14.5 & 15.4 & 16.4 & 17.5 & 18.8 \\
\hline 105 & -1.732 & 0.095 & 14.4 & 15.5 & 18.8 & 21.4 & 14.5 & 15.2 & 16.0 & 17.0 & 18.2 & 19.5 & 21.0 \\
\hline 110 & -1.756 & 0.101 & 15.7 & 17.0 & 20.8 & 23.9 & 15.8 & 16.6 & 17.4 & 18.6 & 20.0 & 21.5 & 23.4 \\
\hline 115 & -1.773 & 0.107 & 17.0 & 18.4 & 22.9 & 26.5 & 17.1 & 18.0 & 19.0 & 20.3 & 21.9 & 23.8 & 26.0 \\
\hline 120 & -1.790 & 0.112 & 18.4 & 20.1 & 25.3 & 29.7 & 18.6 & 19.6 & 20.7 & 22.3 & 24.2 & 26.3 & 29.1 \\
\hline 125 & -1.792 & 0.118 & 20.1 & 22.0 & 28.0 & 33.3 & 20.3 & 21.4 & 22.7 & 24.5 & 26.7 & 29.2 & 32.6 \\
\hline
\end{tabular}


Polish 2012 growth references comparison with the WHO growth standards/references and current German height references

The shape of compared height percentile curves is similar. In the case of boys, the third, 50th, and 97th height percentiles of new Polish and German references overlap almost completely, whereas the WHO growth standar$\mathrm{d} /$ reference percentiles are systematically lower (Fig. 1). In the case of girls, comparison between the new Polish and German height references showed conformity on the third and 50th percentile, whereas body height values of the WHO standards/references are shorter. The differences among height percentiles are smaller on the 97th percentile in all three, compared references, in the age range 3-5 years (Fig. 1). The 2012 Polish boys +2 and +1 BMI $z$ score was consistently higher: $1-2.8$ and $0.2-1$ units, respectively, compared to the WHO BMI standards/references. In the case of girls BMI references the differences yielded: $0.8-1.7$ and $0.3-0.6$ units, respectively, for $+2 \mathrm{SD}$ and $+1 \mathrm{SD}$. In the case of median and $-1 \mathrm{SD}$, and $-2 \mathrm{SD}$, the differences between Polish and the WHO BMI references were not exceeding 0.4 unit (Fig. 2).

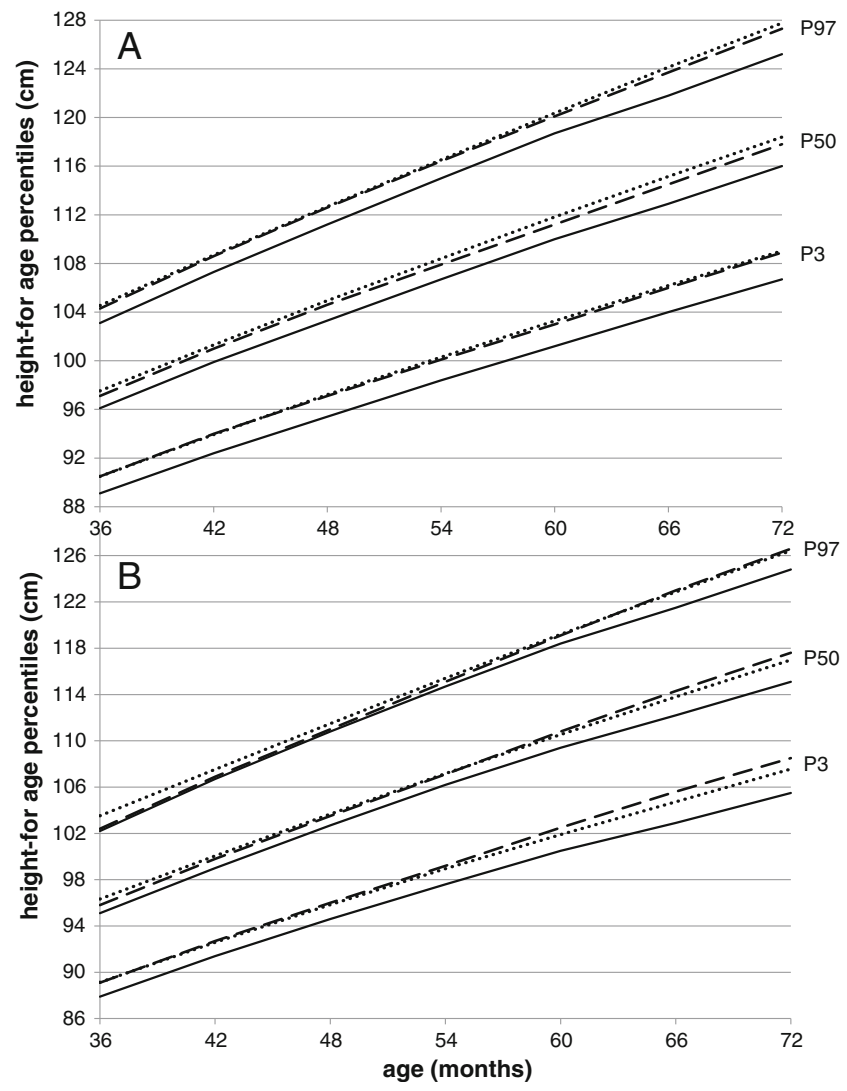

Fig. 1 Height-for-age percentiles (P3; P50; P97): Polish 2012 (dotted line), German (dashed line), and the WHO height standards/references (solid line) for boys (a) and girls (b)

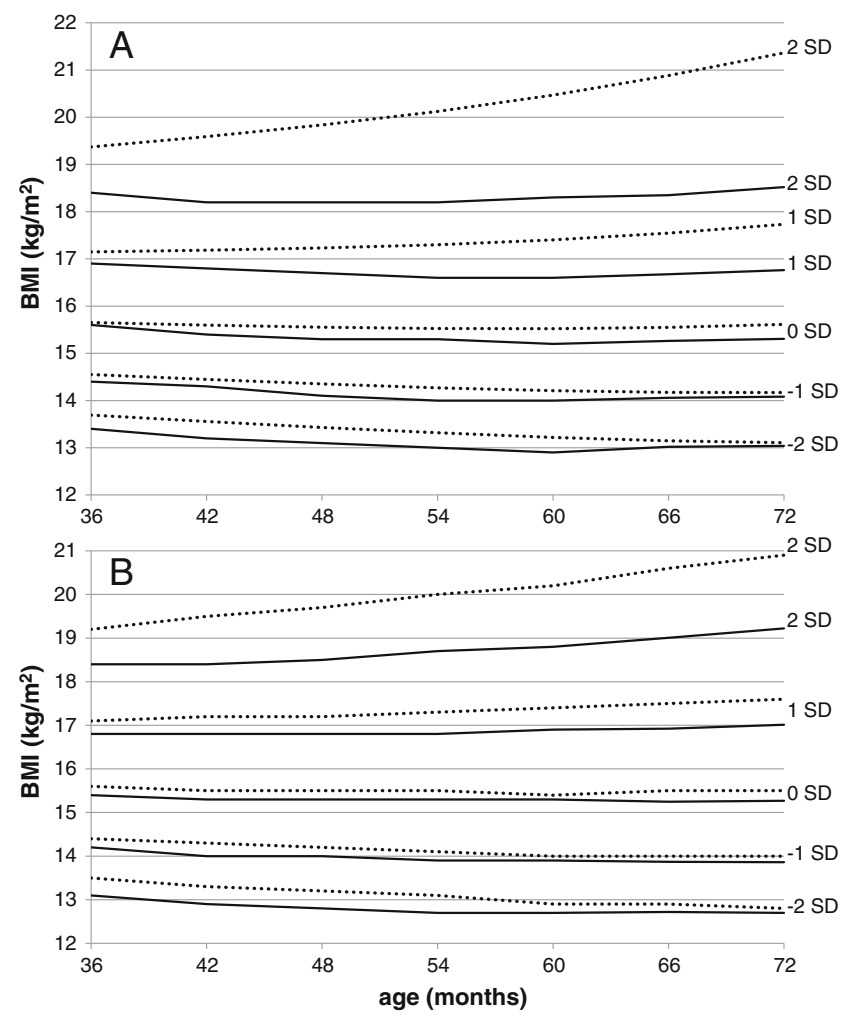

Fig. 2 BMI z-scores of Polish 2012 growth references for preschool children (dotted line) compared to the WHO growth standards/references (solid line) for boys (a) and girls (b)

Polish children aged 3-6 years from a for the nation representative sample, had significantly greater than zero mean $z$ scores of height-, weight-, and BMI-for-age and weight-for-height, relative to the WHO growth standards/references (Table 5). The proportion of children in the sample who were exclusively breastfed for at least 4 months was $41 \%$. In the subsample of children exclusively breastfed, mean HAZ, WAZ, WHZ, and BMIZ, calculated relative to the $\mathrm{WHO}$ growth standards/references, were generally greater than zero and similar to the mean $z$ score in the total sample (Table 5); however, the $95 \% \mathrm{CI}$ included " 0 " in the case of WHZ in 5-year-old boys, WHZ and BMIZ in the case of 5-year-old girls and BMIZ in the case of 6-year-old girls, meaning that the difference is not statistically significant at the level of $5 \%$. In the OLA study sample, the prevalence of stunting according to the WHO growth standards/references was 0.45 and $0.84 \%$, boys and girls, respectively, whereas the prevalence of stunting according to the Polish 2012 height references was 1.97 and $1.84 \%$, boys and girls, respectively. The corresponding percentage of HAZ>+2 SD was 5.80 and $4.04 \%$ compared to the 2.47 and $2.40 \%$, respectively. Differences in prevalence of stunting and percentage of HAZ $>+2$ SD between two compared references were statistically significant, both in the case of boys and girls $(p<0.001)$. 
Table 5 Polish preschool children mean and $95 \%$ CIs of $z$ scores of height, weight, and BMI relative to the $\mathrm{WHO}$ growth standards [24] and references [8]: total sample and children exclusively breastfed for 4 months
$S D$ standard deviation, $C I$ confidence interval of the mean

${ }^{\mathrm{a}}$ For children older than 1,856 days of age WHZ is not available

\begin{tabular}{|c|c|c|c|c|c|c|}
\hline \multirow[t]{2}{*}{ Age (years) } & \multirow[t]{2}{*}{ Variable } & \multicolumn{2}{|l|}{ Total sample } & \multicolumn{3}{|c|}{ Exclusive breastfeeding for 4 months } \\
\hline & & Mean (SD) & $95 \% \mathrm{CI}$ & $N(\%$ in the sample $)$ & Mean (SD) & $95 \% \mathrm{CI}$ \\
\hline \multicolumn{7}{|l|}{ Boys } \\
\hline \multirow[t]{4}{*}{3} & HAZ & $0.40(1.01)$ & $0.32-0.48$ & \multirow[t]{4}{*}{$233(39.2 \%)$} & $0.36(0.99)$ & $0.23-0.49$ \\
\hline & WAZ & $0.44(1.14)$ & $0.35-0.54$ & & $0.40(1.06)$ & $0.26-0.53$ \\
\hline & WHZ & $0.32(1.13)$ & $0.22-0.41$ & & $0.27(1.05)$ & $0.14-0.40$ \\
\hline & BMIZ & $0.25(1.14)$ & $0.16-0.34$ & & $0.22(1.05)$ & $0.08-0.35$ \\
\hline \multirow[t]{4}{*}{4} & HAZ & $0.39(0.99)$ & $0.32-0.47$ & \multirow[t]{4}{*}{$273(41.0 \%)$} & $0.37(1.00)$ & $0.25-0.49$ \\
\hline & WAZ & $0.45(1.09)$ & $0.37-0.54$ & & $0.43(1.05)$ & $0.31-0.56$ \\
\hline & WHZ & $0.30(1.15)$ & $0.21-0.39$ & & $0.29(1.06)$ & $0.16-0.41$ \\
\hline & BMIZ & $0.31(1.20)$ & $0.22-0.40$ & & $0.30(1.11)$ & $0.17-0.43$ \\
\hline \multirow[t]{4}{*}{5} & HAZ & $0.41(0.96)$ & $0.33-0.48$ & \multirow[t]{4}{*}{$268(43.6 \%)$} & $0.41(0.92)$ & $0.30-0.52$ \\
\hline & WAZ & $0.43(1.14)$ & $0.34-0.52$ & & $0.42(1.12)$ & $0.28-0.55$ \\
\hline & WHZ & $0.12(1.09)$ & $0.00-0.23$ & & $0.13(1.04)$ & $-0.04-0.30$ \\
\hline & BMIZ & $0.25(1.22)$ & $0.15-0.35$ & & $0.22(1.21)$ & $0.08-0.37$ \\
\hline \multirow[t]{3}{*}{$6^{\mathrm{a}}$} & HAZ & $0.48(1.07)$ & $0.39-0.57$ & \multirow[t]{3}{*}{$232(41.4 \%)$} & $0.48(1.06)$ & $0.34-0.61$ \\
\hline & WAZ & $0.49(1.27)$ & $0.38-0.59$ & & $0.48(1.15)$ & $0.33-0.63$ \\
\hline & BMIZ & $0.25(1.30)$ & $0.14-0.36$ & & $0.25(1.13)$ & $0.10-0.40$ \\
\hline \multicolumn{7}{|l|}{ Girls } \\
\hline \multirow[t]{4}{*}{3} & HAZ & $0.33(1.01)$ & $0.25-0.41$ & \multirow[t]{4}{*}{$218(37.5 \%)$} & $0.44(1.00)$ & $0.31-0.57$ \\
\hline & WAZ & $0.40(0.99)$ & $0.32-0.48$ & & $0.49(0.94)$ & $0.36-0.61$ \\
\hline & WHZ & $0.30(0.99)$ & $0.22-0.38$ & & $0.34(0.94)$ & $0.22-0.47$ \\
\hline & BMIZ & $0.28(1.01)$ & $0.20-0.36$ & & $0.31(0.98)$ & $0.18-0.44$ \\
\hline \multirow[t]{4}{*}{4} & HAZ & $0.22(0.95)$ & $0.15-0.29$ & \multirow[t]{4}{*}{$278(40.2 \%)$} & $0.17(0.91)$ & $0.06-0.27$ \\
\hline & WAZ & $0.31(1.07)$ & $0.23-0.39$ & & $0.26(0.94)$ & $0.15-0.37$ \\
\hline & WHZ & $0.28(1.11)$ & $0.19-0.36$ & & $0.25(0.91)$ & $0.15-0.36$ \\
\hline & BMIZ & $0.27(1.12)$ & $0.19-0.36$ & & $0.24(0.91)$ & $0.13-0.35$ \\
\hline \multirow[t]{4}{*}{5} & HAZ & $0.27(0.98)$ & $0.19-0.34$ & \multirow[t]{4}{*}{$268(40.7 \%)$} & $0.30(0.97)$ & $0.18-0.41$ \\
\hline & WAZ & $0.25(1.07)$ & $0.17-0.33$ & & $0.26(1.05)$ & $0.13-0.38$ \\
\hline & WHZ & $0.05(0.98)$ & $-0.04-0.15$ & & $0.00(0.94)$ & $-0.15-0.14$ \\
\hline & BMIZ & $0.14(1.08)$ & $0.05-0.22$ & & $0.11(1.07)$ & $-0.02-0.24$ \\
\hline \multirow[t]{3}{*}{$6^{\mathrm{a}}$} & HAZ & $0.38(1.00)$ & $0.30-0.47$ & \multirow[t]{3}{*}{$241(42.1 \%)$} & $0.35(0.98)$ & $0.23-0.48$ \\
\hline & WAZ & $0.34(1.13)$ & $0.24-0.43$ & & $0.32(1.13)$ & $0.17-0.46$ \\
\hline & BMIZ & $0.15(1.15)$ & $0.05-0.24$ & & $0.14(1.12)$ & $-0.01-0.28$ \\
\hline
\end{tabular}

\section{Discussion}

This paper provides for the first time growth references for Polish preschool children based upon a contemporary, crosssectional, nationally representative sample. The state-of-theart statistical methodology was employed to develop the references. Although we excluded data from children with known disorders affecting growth for growth references elaboration, the presented standard deviation scores and percentiles should be considered as a growth references (not a growth standards according to the WHO terminology [24]), because we did not identify environmental conditions "likely to favor the achievement of children's full genetic growth potential" [24].
In this paper, we present weight-for-height references, which are particularly useful in assessing a nutritional status of patients and in screening both underweight and overweight in children. The weight-for-height and BMI-for-age have similar characteristics with regard to the detection of underweight or overweight in children [17]. The advantage of using weight-for-height is that it provides quick assessment of the nutritional status without the need to perform any calculations for estimation of underweight, normal, or overweight. Therefore the weight-for-height is preferred by some practitioners.

The height, weight, and BMI of Polish children from the OLA study differ significantly from growth reference developed by the WHO. It is yet another evidence for using 
local, population-specific references of anthropometric traits [2]. According to the results of the OLA study, using universal referential values may lead to missed diagnosis of delayed growth or to erroneous diagnosis of accelerated growth. The comparison of our normative data with referential values published by the WHO showed that number of children diagnosed with stunting (height-for-age below -2 $\mathrm{SD})$ was significantly lower than expected and number of children with height-for-age above +2 SD was significantly higher than expected. Therefore, some of children with delayed growth could be falsely diagnosed as healthy whereas number of children with tall stature would be higher using international growth standards. Adoption of the WHO growth standards may lead to uncertainty as regard referral criteria and variations in general practitioners' referral rates. It may also influence specialized pediatric clinical care since, for example, in Poland comparison of individual child's height to the height references is required entry criterion to the treatment with growth hormone (height below third percentile for age, equivalent of $-1.88 \mathrm{SD}$ ) [7]. Using ethnic and geographically specific growth charts in children is especially important in the era of migration and globalization. The findings of the OLA study are consistent with results of Belgian and Norwegian children analysis with regard to the age-adjusted prevalence of height below -2 SD [14] and UK data with regard to the $\mathrm{BW}, \mathrm{WAZ}$, and BMIZ comparison to the WHO growth standards [26].

The MGRS sample consisted of children exclusively breastfed for at least 4 months. In Poland breastfeeding is recommended, however less than $50 \%$ of infants are exclusively breastfed for 4-6 months $[6,25]$. In the representative sample of preschool children of the OLA study, $41 \%$ of parents reported exclusive breastfeeding for 4 months. This subsample of children does not substantially differ with regard to the height, weight, and BMI at ages 3-6 years, compared to the total sample, consisting of majority (59\%) non-exclusively breastfed during infancy, children. The growth pattern of breastfed children in the OLA study was more alike national references than the WHO standards which is in line with findings of Belgian and Norwegian researchers [14].

Childhood overweight and obesity is a global problem reaching epidemic proportions [13]. Unlike for the adult population, there is no uniform definition for overweight and obese children. It is generally agreed that adiposity in childhood is measured as BMI $[1,12]$. However, since there is no clinically defined, health-risk-related cut-off levels for increased BMI in childhood, population-based distributions of BMI are used for this purpose. The differences presented with regard to the OLA study sample and the MGRS BMI distribution indicate shift of the upper tail of BMI distribution in Polish children compared to the universal sample.
However, it is worth noting that the values defined by +1 SD curve of BMI distribution of the OLA study are more close to the International Obesity Task Force (IOTF) overweight cut-off points [4], whereas corresponding values of the WHO growth standards are lower. Decision on adopting any specific BMI reference would affect rates of overweight in children: higher in the case of the WHO growth standards and lower in the case of IOTF and the OLA study reference.

Concluding, we present growth references for Polish preschool children based on analysis of data obtained from representative sample of children aged 3-6 years. We found significant differences in growth traits between countryspecific and universal growth references published by the WHO. These differences should be taken into consideration when the references are applied. The OLA study growth references can be recommended as national references for preschool children.

Acknowledgments The OLA study was supported by a grant from the National Centre for Research and Development; grant number: $\mathrm{N}$ R13 000206.

The following investigators, in addition to those listed as authors, participated in the OLA study: Bełchów: Danuta Moskwa, Andrzej Smalc; Biała Piska: Krystyna Skarzyńska; Biała Podlaska: Wiesława Jakubowska; Białystok: Justyna Tymińska-Zimnoch; Bielsk: Katarzyna Wiankowska; Brójce: Dariusz Kliszcz; Bydgoszcz: Ewa Rafalska; Celestynów: Dorota Malinowska; Charsznica: Maria Bogacz; Czernikowo: Halina Świątkowska; Damnica: Barbara Zawadzka; Dobre: Anna Nowicka; Drążżewo: Dariusz Kossakowski; Gliwice: Jolanta Białek-Kaleta, Renata Karpiel; Gołańcz: Zenon Borucki; Gorzów Śląski: Renata Stefan; Górzno: Stanisław Masny; Gracze: Jacek Ciepluch; Jasło: Lucyna Mikrut, Janina Pięta; Jastrzębia: Renata Nowak; Jelenia Góra: Olga Knap, Elżbieta Laszczyk; Jędrzejów: Marta Łysek; Katowice: Aleksandra Mizera-Błaszczyk, Ewa Wiśniewska; Kołobrzeg: Ewa Kogutowicz-Reichel; Koronowo: Ryszard Tausz; Korzeniew: Błażej Ciamciak; Koszęcin: Adam Konina; Kraków: Julita Pabisek-Miernik, Urszula Stoncel, Małgorzata Wójcik; Książenice: Hanna Pawłowska; Lipiany: Paweł Zujko; Lipnica: Małgorzata Ogiejko-Szukała, Elżbieta Zielińska; Lubanie: Justyna Juralewicz; Lublin: Elżbieta Kotyrba, Urszula Pszczoła; Luboń: Hanna Olejniczak; Łagów: Ewa Wielgus-Aplas; Łódź: Urszula Górska, Marek Kasielski; Łubniany: Barbara Średzka-Burman; Mielec: Bogumiła Jachym, Tadeusz Zięba; Mieroszów: Lucyna Polańska, Piotr Polański; Mikstat: Kazimierz Kulikowski; Nakło nad Notecią: Monika Albrewczyńska; Niemodlin: Barbara Konior; Nowy Dwór Gdański: Lech Pietras; Nowy Sącz: Lucyna Aschenbrenner, Irena Skowrońska, Alicja Wajrak-Fałowska; Olsztyn: Janusz Sielczak, Urszula Wiśniewska; Osiek: Zbigniew Jeczeń; Osielsko: Anna Żyta-Jazdon; Ostrożany: Maciej Wasilewski; Pakosław: Ewa Cempel-Nowak; Pleszew: Ewa Zdunek-Krawczyk; Poznań: Beata Wojciechowska-Martin; Przechlewo: Jacek Jastrzębski; Przesmyki: Anna Pożarowszczyk-Osik; Radzionków: Marzena Nordyńska-Sobczak; Reszel: Alicja Chałupa-Bońkowska, Krystyna Szczepańska; Rożnów: Aleksander Więcek; Ruda Śląska: Teresa Seweryn; Sępólno Krajeńskie: Teresa Ruthendorf-Przewoska; Sławno: Marzena Aurelia Paczkowska; Strzelce Opolskie: Marek Skrzypulec; Szczebrzeszyn: Urszula Chmura-Rozwadowska; Szczecin: Barbara Glura, Ewa Tomasik; Szczytno: Czesława Woźniak; Tarnów: Małgorzata Barnaś, Grażyna Rybczyk; Urzejowice: Władysław Liwak; Ustka: Elżbieta Barlik, Jolanta Roman, Grażyna Rostkowska, Krystyna Żelezik-Serafin; Warszawa: Anna Kwiatkowska, Małgorzata Mazurek, Weronika Michalec, Natalia Niedziela, Elżbieta Nowicka-Bursa, Małgorzata Nowosad, Grażyna Siemion, Alina Terlecka, Urszula Wyrzykowska, Małgorzata Zawiślak; 
Wieluń: Katarzyna Puławska; Wisznice: Ryszard Chustecki; Wodzisław Śląski: Jadwiga Rakszawska; Wolin: Wanda Aleksandra Jasiewicz; Wołomin: Maria Mikoszewska-Żołędziowska, Anna Uthke-Kluzek; Wrocław: Elżbieta Bombała, Monika Predko, Beata Stecka, Zuzanna Wolak-Listwan; Wysoka: Tomasz Domagalsk; Zabrze: Jolanta Chelus, Joanna Konieczna-Czmiel, Edyta Mordka, Karolina Ziółkowska; Zegartowice: Kazimierz Piotrowicz; Zgorzelec: Elżbieta ZarzyckaŻmiejko; Zielona Góra: Maria Zapotoczna; Złoczew: Anna Rakowska.

Conflict of interest The authors declare that they have no conflict of interest, i.e., the authors have no financial relationship with the organization that sponsored the research.

Open Access This article is distributed under the terms of the Creative Commons Attribution License which permits any use, distribution, and reproduction in any medium, provided the original author(s) and the source are credited.

\section{References}

1. Barlow SE, Dietz WH (1998) Obesity evaluation and treatment: Expert committee recommendations. Pediatrics] 102:e29. URL: http://www.pediatrics.org/cgi/content/full/102/3/e29

2. Bonthuis M, van Stralen KJ, Verrina E, Edefonti A, Molchanova EA, Hokken-Koelega AC, Schaefer F, Jager KJ (2012) Use of national and international growth charts for studying height in European children: development of up-to-date European heightfor-age charts. PLoS One 7(8):e42506. doi:10.1371/ journal.pone.0042506

3. Cole TJ (1990) The LMS method for constructing normalized growth standards. Eur J Clin Nutr 44:45-60

4. Cole TJ, Bellizzi MC, Flegal K, Dietz WH (2000) Establishing a standard definition for child overweight and obesity worldwide: international survey. BMJ 320:1240-1243

5. Cole TJ (2006) Growth references and standards. In: Cameron $N$ (ed) Human growth and development. Academic Press, London, pp 383-413

6. Ćwiek D, Branecka-Woźniak D, Fryc D, Grochans E, Malinowski W (2010) Reasons for giving up breastfeeding and support during problems with lactation in the north-western part of Poland. Ann Acad Med Stetin 56(2):129-32

7. Decree of the Minister of Health of 26th of October $2012 \mathrm{http}: / /$ www.mz.gov.pl/wwwfiles/ma_struktura/docs/obwieszczenie_4_ 26102012.pdf accessed $7^{\text {th }}$ of November 2012

8. de Onis M, Onyango AW, Borghi E, Siyam A, Nishida C, Siekmann J (2007) Development of a WHO growth reference for school-aged children and adolescents. Bull World Health Organ 85:660-667

9. de Onis M, Woynarowska B (2010) WHO child growth standards for children $0-5$ years and the possibility of their implementation in Poland. Med Wieku Rozwoj 14:87-94

10. Free download: http://www.who.int/childgrowth/software/en/ accessed 27th of July 2012
11. Free download: http://www.who.int/growthref/tools/en/ accessed 27th of July 2012

12. Hall DMB, Cole TJ (2006) What use is the BMI? Arch Dis Child 91:283-286

13. Han JC, Lawlor DA, Kimm SYS (2010) Childhood obesity. Lancet 375:1737-1748

14. Juliusson PB, Roelants M, Hoppenbrouwers K, Hauspie R, Bjerknes R (2011) Growth of Belgian and Norwegian children compared to the WHO growth standards: prevalence below -2SD and above $+2 \mathrm{SD}$ and the effect of breastfeeding. Arch Dis Child 96:916-921

15. Kułaga Z, Litwin M, Tkaczyk M, Palczewska I, Zajączkowska M, Zwolińska D, Krynicki T, Wasilewska A, Moczulska A, Morawiec-Knysak A, Barwicka K, Grajda A, Gurzkowska B, Napieralska E, Pan H (2011) Polish 2010 growth references for school-aged children and adolescents. Eur J Pediatr 170:599-609

16. Kulaga Z, Litwin M, Tkaczyk M, Rózdzyńska A, Barwicka K, Grajda A, Swiader A, Gurzkowska B, Napieralska E, Pan H (2010) The height-, weight-, and BMI-for-age of Polish school-aged children and adolescents relative to international and local growth references. BMC Publ Health 10:109

17. Mei Z, Grummer-Strawn LM, Pietrobelli A, Goulding A, Goran MI, Dietz WH (2002) Validity of body mass index compared with other body-composition screening indexes for the assessment of body fatness in children and adolescents. Am J Clin Nutr 75:978985

18. Palczewska I, Niedzwiedzka Z (2001) Somatic development indices in children and youth of Warsaw. Med Wieku Rozwoj 5(Suppl 1):18-118

19. Pan H, Cole TJ (2000) LMSchartmaker, a program to construct growth references using the LMS method Version $2.42 \mathrm{http}: / /$ www.healthforallchildren.co.uk. Accessed 25 April 2010

20. Pan H, Cole TJ (2004) A comparison of goodness of fit tests for age-related reference ranges. Stat Med 23:1749-1765

21. Rosario AS, Schienkiewitz A, Neuhauser H (2011) German height references for children aged 0 to under 18 years compared to WHO and CDC growth charts. Ann Hum Biol 38:121-130

22. Royston P, Wright EM (2000) Goodness-of-fit statistics for agespecific reference intervals. Stat Med 19:2943-2962

23. van Buuren S, Fredriks M (2001) Worm plot: a simple diagnostic device for modelling growth reference curves. Stat Med 20:12591277

24. WHO Multicentre Growth Reference Study Group (2006) WHO child growth standards: length/height-for-age, weight-for-age, weight-for-length, weight-for-height and body mass index-forage: methods and development. World Health Organization, Geneva

25. Wojdan-Godek E, Mikiel-Kostyra K, Mazur J (2000) Factors associated with exclusive breastfeeding of infants in Poland. Med Wieku Rozwoj 4(3 Suppl 1):15-24

26. Wright C, Lakshman R, Emmett P, Ong KK (2008) Implications of adopting the WHO 2006 child growth standard in the UK: two prospective cohort studies. Arch Dis Child 93:566-569 